\title{
Study of Dissolved Organic Carbon Concentration in KHDTK Forest Peatland Area, Central Kalimantan, Indonesia
}

\author{
Galih Widhi Pratama'), Fengky F. Adji ${ }^{2)}$, Panji Surawijaya ${ }^{2)}$, Nina Yulianti²), \\ Zafrullah Damanik ${ }^{2)}$
}

1) Department of Agronomy, Faculty of Agriculture, Palangka Raya University, Indonesia

2) Faculty of Agriculture, Palangka Raya University, Indonesia

\begin{abstract}
The study was conducted to determine whether are differences in dissolved organic carbon (DOC) in three different types of peatland conditions. The study was conducted from March $1^{\text {st }}$ to April 30, 2020. The research was carried out in the Tumbang Nusa Special Purpose Forest Area (KHDTK). Furthermore, the analysis of DOC samples was carried out at the BALITRA Laboratory, Banjar Baru, South Kalimantan. The analysis of water $\mathrm{pH}$ samples was conduct at the UPT. LLG - CIMTROP, UPR Laboratory. The results showed that DOC in degraded peatlands site ranged from $36.18 \mathrm{mg} \mathrm{L}^{-1}$ to $76.86 \mathrm{mg} \mathrm{L}^{-1}$ with an average of $53.1 \mathrm{mg} \mathrm{L}^{-1}$, water $\mathrm{pH}$ between 3.6 to 4 with an average of 3.88 , and the water table of $26.51 \mathrm{~cm}$. Then in the forest site ranged from $37.12 \mathrm{mg} \mathrm{L}^{-1}$ to $49.81 \mathrm{mg} \mathrm{L}^{-1}$ with an average of 40.95 $\mathrm{mg} \mathrm{L}^{-1}$, water $\mathrm{pH}$ ranged of 4 to 4.4 with an average of 4.32 , and water table $-5.13 \mathrm{~cm}$. Furthermore, the re-vegetation site ranged from $29.27 \mathrm{mg} \mathrm{L}^{-1}$ to $34.90 \mathrm{mg} \mathrm{L}^{-1}$ with an average of $30.73 \mathrm{mg} \mathrm{L}^{-1}$, water $\mathrm{pH}$ between 4 to 4.3 with an average of 4.18 , and water table $36.28 \mathrm{~cm}$. Based on the results of the study it can be concluded that there is a difference in DOC in three sites, in the degradation site contributes higher dissolved organic carbon than other sites with an average amount of $53.1 \mathrm{mg} \mathrm{L}^{-1}$, compared to forest site with an average amount of $40.95 \mathrm{mg} \mathrm{L}^{-1}$, and re-vegetation site with an average amount of $30.73 \mathrm{mg} \mathrm{L}^{-1}$. Therefore, sustainable management of peat is expected to minimize the rapid decomposition of organic material in peat.
\end{abstract}

Keywords: Dissolved Organic Carbon, Secondary forest, Degradation and Revegetation.

\section{Introduction}

The area of tropical peatlands turns out to be only eight percent of the total peatland in the world which reached 400 million ha as of February 2016. As much as 60 percent of tropical peatlands are in Southeast Asia. In the latest data, the area of peatlands in Indonesia shows about 13.25 million ha spread over Sumatra, Kalimantan, and Papua (Ritung et al., 2011) in Muhamad et al 2015. The widest distribution is in the provinces of Riau, Papua, Central Kalimantan, West Kalimantan. , and South Sumatra. Central Kalimantan province has 3 million hectares of tropical peatlands; $52 \%$ of the total Kalimantan and $8 \%$ of the rest of the world. These peatlands contain nearly $70 \%$ of the total forest biomass in Central Kalimantan and a carbon stock that is 9 gigatons on the surface. These carbon stocks are at great risk from threats from agriculture, mining, and forestry. The provincial (local) government, carbon emission monitor, found that in the normal business scenario. Central Kalimantan's remaining lowland forest is one of the world's richest species habitats and its peat swamp forest holds a unique assemblage of plants and animals.

Organic carbon in rivers plays an important role in the carbon cycle linking terrestrial carbon to marine carbon (Baum et al. 2007), but organic carbon from natural and artificial channels around peatlands is under-accounted for in the current global carbon cycle (Riche et al. 2002). Hope et al. (1997) explained that peatlands are the main source of carbon in the channel (natural and artificial), the amount of carbon concentration in the channel is strongly influenced by the distribution of peat around the channel, so to measure the concentration of organic carbon in the channel must also measure the concentration of organic carbon in peat groundwater.

Carbon in peat water consists mostly of organic carbon, which can be dissolved organic carbon (DOC), and particulate organic carbon (POC). The difference between the two components is generally based on whether it passes through filter paper with a pore size of $0.7 \mathrm{~m}$ or not, DOC passes through the filter while POC is filtered 
(Billett et al. 2006). The number of DOC and POC is total organic carbon (TOC), where DOC is the most dominant organic carbon in water sourced from peatlands (IPCC 2014) in Muhamad et al 2015.

\section{Formulation of the problem}

The formulation of the problem in this study is whether there are differences in dissolved organic carbon between 3 (three) types of peatland conditions, namely natural secondary peatlands and degraded peatlands that have been burned and revegetated peatlands.

\section{Research purposes}

Based on some of the problems above, the study aimed to determine dissolved organic carbon in 3 (three) different types of peatland conditions.

\section{Hypothesis}

Based on 3 (three) different types of inland peatland conditions, there are differences in dissolved organic carbon in secondary natural land, burnt land, and revegetation land, which are influenced by environmental factors.

\section{Methods}

The research was carried out for 2 months starting from March 2020 to April 2020. The research site was at KHDTK Tumbang Nusa. Furthermore, soil sample analysis was carried out by the UPT CIMTROP UPR Laboratory, the Laboratory of the Department of Agricultural Cultivation, Palangka Raya University, and the BALITRA Laboratory, South Kalimantan.

The materials used to extract Dissolved Organic Carbon (DOC) in peat soil is soda lime. While the tools used are machetes, PVC pipes, hoses, injections, stopwatches, soil temperature gauges, cameras, $\mathrm{pH}$ meters, EC meters, sample rings, and stationery.

This research is a descriptive study by measuring directly on several types of land use. The research was conducted by sampling method at each different land cover. Each research location was given 5 PVC pipes, each of which has a different size, namely $50 \mathrm{~cm}, 100 \mathrm{~cm}, 150 \mathrm{~cm}, 200$ $\mathrm{cm}$, and $250 \mathrm{~cm}$.

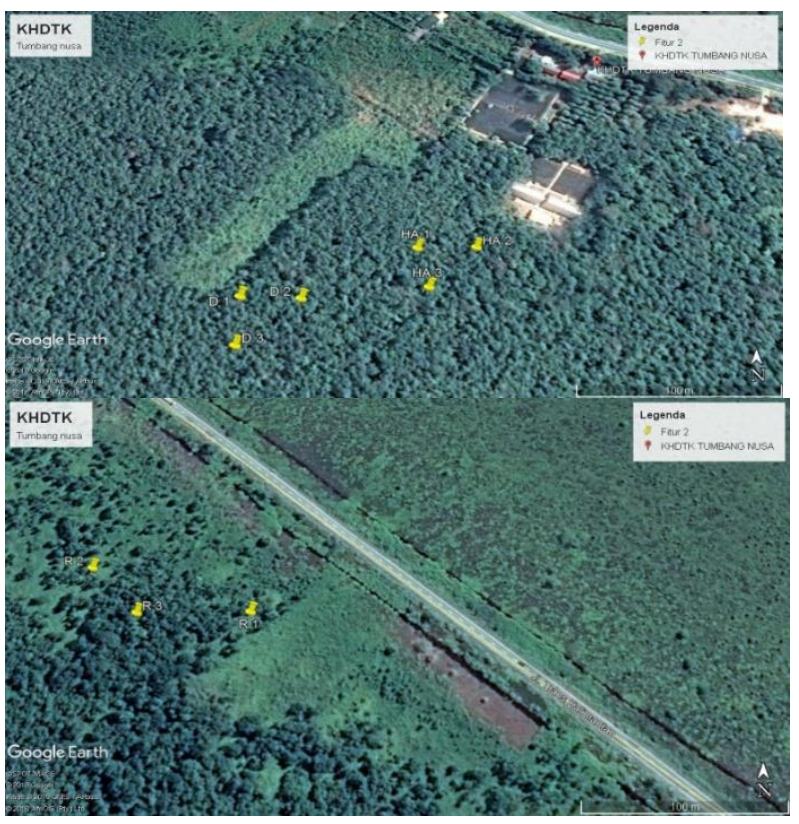

Figure 1. Sampling Map

(Source: Google earth)

\section{Research Implementation}

\section{Selection and Determination of Research Site}

The research location was carried out on peat soil with 3 (three) types of land use, namely:

1. Natural Secondary Forest Land

Secondary forest land is forest land that grows and develops naturally after land clearing or damage to the forest land occurs.

2. Degraded land after burning

Degraded land is a decrease or decrease or even loss of use, or potential use or replacement of diversity or loss of organisms that cannot be replaced. Land degradation can also be in the form of a decrease in some kind of alternative land use or the status of its use.

3. Restored/revegetated peatlands.

Land restoration is an action to make an ecosystem that has been degraded back as close as possible to its original condition. 
Table 1. Measurement of Dissolved Organic Carbon Content with 3 types of land use

\begin{tabular}{cll} 
No. & Landuse & Coordinate \\
\hline 1 & Natural Forest & E: $114^{\circ} 05.420^{\prime}$ \\
& & S: $02^{\circ} 21.280^{\prime}$ \\
2 & Ex-Fire & E: $114^{\circ} 05.360^{\prime}$ \\
3 & & S: $02^{\circ} 21.352^{\prime}$, \\
& Revegetation & E: $114^{\circ} 05.232^{\prime}$ \\
& & S: $02^{\circ} 20.235^{\prime}$ \\
\hline
\end{tabular}

Dissolved Organic Carbon Sampling in the Field.

Sampling of Dissolved Organic Carbon in the field was carried out using the injection method or the injection method for collecting peat water in the peralon in February 2020.

\section{How it works for the injection method.}

a) Prepare the syringe and the place to be used for filling peat water.

b) Sucking peat water in the PVC pipe that has been prepared.

c) After suctioning the water in the injection, it is inserted into the prepared container, at least the container used is $100 \mathrm{ml}$.

d) After that, label or code the sample so that the sample is not confused with another sample.

e) After that, the measurement of dissolved organic carbon took place at the BALITRA Laboratory, Banjar Baru, South Kalimantan, using the Auto Analyzer method.

\section{Obstacle if the pipe sinks}

If the PVC pipe planted at the research site sinks, you can use the following methods:

a) Unplug the PVC pipe that has been planted.

b) Connect the PVC pipe with the same size as the old PVC pipe.

c) Clean the old PVC pipe.

d) Replant the PVC pipe that has been connected.

e) Wait for 2-3 hours, then take a water sample by the injection method.
Measurement of Groundwater Level (WT) Fluctuation or Depth (WT)

1. PVC pipe to measure groundwater fluctuations (size inch) with a length of 1.5 meters is plugged into the ground as deep as $\pm 80 \mathrm{~cm}$.

2. Measurement of ground water level using a water level sensor.

3. Groundwater depth is the difference between the length of the cable section that touches the groundwater in the PVC pipe and the height of the pipe from the ground.

Table 2. Research Variable

\begin{tabular}{lll}
\hline No & Variable & Methods \\
\hline 1 & DOC & Auto Analyzer \\
\hline 2 & pH of water & pH meter \\
\hline 3 & WT Depth & Manual \\
\hline 4 & Rainfall & Secondary data (BMKG) \\
\hline
\end{tabular}

\section{Data analysis}

The data from the field measurements are presented in the form of tables and graphs and then continued by connecting environmental factors with dissolved organic carbon (DOC) content, using the Ms. Excel. 
Table 3. Water Table (WT in $\mathrm{cm}$ ) Parameters and Rainfall Data

\begin{tabular}{ccccc}
\hline Date & $\begin{array}{c}\text { Rainfall } \\
(\mathrm{mm})\end{array}$ & Degraded & Forest & Revegetation \\
\hline $24 / 3 / 2019$ & 0 & 27.97 & -2.47 & 33.2 \\
$31 / 3 / 2019$ & 1.7 & 24.73 & -14.2 & 28.8 \\
$7 / 4 / 2019$ & 0 & 24.33 & -5.33 & 31.13 \\
$14 / 4 / 2019$ & 13.1 & 26 & -7.67 & 69.67 \\
$21 / 4 / 2019$ & 7.6 & 23.6 & -10.33 & 31.4 \\
$28 / 4 / 2019$ & 55.4 & 28.07 & -0.67 & 32.53 \\
$5 / 5 / 2109$ & 0 & 29.27 & -3.07 & 30.8 \\
$12 / 5 / 2019$ & 5.4 & 28.13 & 2.67 & 32.67 \\
\hline Average & 10.4 & 26.51 & -5.13 & 36.28 \\
\hline
\end{tabular}
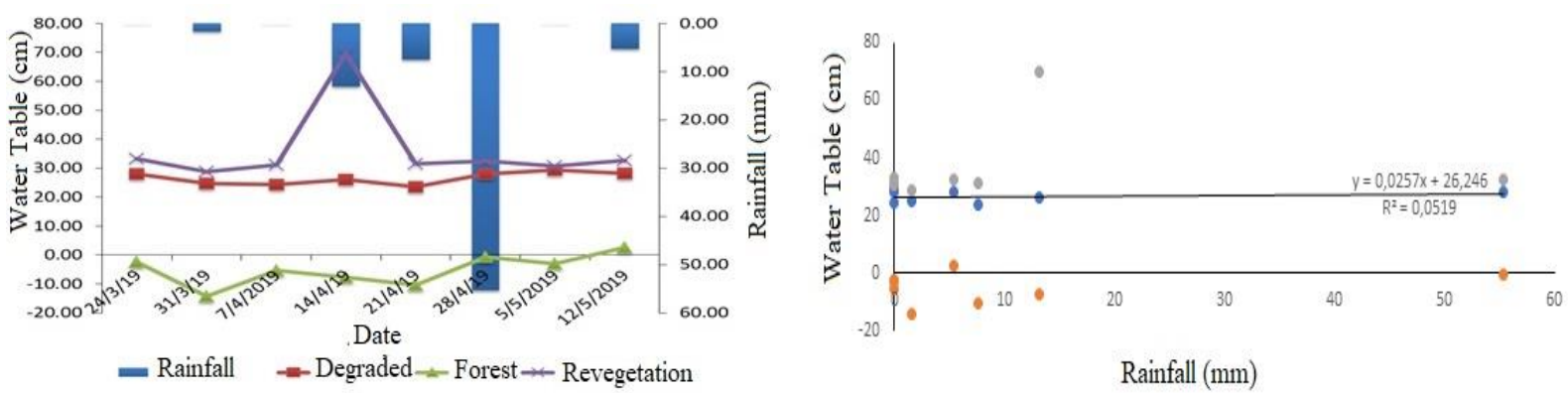

Figure 2. Water Table and rainfall (left) and Correlation between Water Table and Rainfall

\section{Results and Discussion}

\section{a. Results}

\section{Water Table (WT)}

The environmental parameters measured (Table 3) are three (3) land conditions: land conditions. Degradation, namely land that is degraded (ever burned) with environmental vegetation dominated by malevolence with a water table ranging from $23.6 \mathrm{~cm}$ to $29.27 \mathrm{~cm}$, with an average of $26.51 \mathrm{~cm}$ (ground water level is $26.51 \mathrm{~cm}$ above the ground); while the condition of forest land with vegetation of a secondary natural forest environment where the forest is overgrown with forest plants with a water table value ranging from $-10.33 \mathrm{~cm}$ to $2.67 \mathrm{~cm}$, with an average of $-5.13 \mathrm{~cm}$ (ground water level below ground level as deep as $5.13 \mathrm{~cm}$ ); while on Revegetation land, namely land that has been revegetated or restored (ever burned) with a groundwater level ranging from $28.8 \mathrm{~cm}$ to 69.67 $\mathrm{cm}$, with an average of $36.28 \mathrm{~cm}$ (ground water level is above ground level). $36.28 \mathrm{~cm}$ ).

The results of the rainfall data obtained from the Central Kalimantan BMKG, showed that the rainfall in the study area ranged from 0 to $55.4 \mathrm{~mm}$. The highest rainfall was on April 28, 2019 with a value of $55.4 \mathrm{~mm}$. The lowest rainfall was on March 24, 2019, April 7, 2019, and May 5, 2019 with a value of $0 \mathrm{~mm}$. The rainfall data got an average of $10.4 \mathrm{~mm}$. 


\section{Dissolved Organic Carbon (DOC)}

Table 4. DOC at several landuses

\begin{tabular}{llll}
\hline V\K & Degraded & Forest & Revegetation \\
\hline 50 & 4.2 & 4.4 & 4.3 \\
100 & 3.6 & 4 & 4.3 \\
150 & 3.6 & 4.4 & 4.3 \\
200 & 4 & 4.4 & 4 \\
250 & 4 & 4.4 & 4 \\
\hline Avg. & 3.88 & 4.32 & 4.18 \\
\hline
\end{tabular}

The results of the measurement of the average Dissolved Organic Carbon (DOC) (Table 4) at the degradation site ranged from $36.18 \mathrm{mg} \mathrm{l}^{-1}$ to $76.86 \mathrm{mg} \mathrm{l}^{-1}$ with an average of $53.1 \mathrm{mg} \mathrm{l}^{-1}$. Then in forest locations it ranged from $37.12 \mathrm{mg} \mathrm{l}^{-1}$ to $49.81 \mathrm{mg} \mathrm{l}^{-1}$ with an average value of $40.95 \mathrm{mg} \mathrm{l}^{-1}$, then at Revegetation locations it ranged from $29.27 \mathrm{mg} \mathrm{l}^{-1}$ to $34,90 \mathrm{mg} \mathrm{l}^{-1}$ with an average of $30.73 \mathrm{mg} \mathrm{l}^{-1}$. Based on the results of the measurement of Dissolved Organic Carbon, it turns out that the degradation location of dissolved organic carbon is higher $\left(53.1 \mathrm{mg} \mathrm{l}^{-1}\right)$ than other locations.

\section{b. Discussion}

\section{Water Table and Rainfall}

From the observations above, it shows that the presence of rainfall strongly influences the water table, the higher the intensity of the rainfall, the higher the water table. The highest rainfall occurred on 28-04-2019 with a value of $55.4 \mathrm{~mm}$, where on the same date the water table conditions increased in height from each location. The water table (WT) in peatlands generally follows variations in rainfall, namely shallow or close to the soil surface in the rainy season, and deep below the soil surface in the dry season. In general, the water level near the channel is also deeper than the water level in the land far from the channel. This happens because of the nature of water that always flows to a lower place. Therefore, the construction of canals on peatlands plays an important role in maintaining the water level on the land.

The average WT on this burned land, which is $26.51 \mathrm{~cm}$, shows different results from WT on different land conditions on peatlands. This is likely due to the different intensity of fires between lands, where the bigger and more frequent the fires
Figure 3. Dissolved Organcik Carbon (DOC)

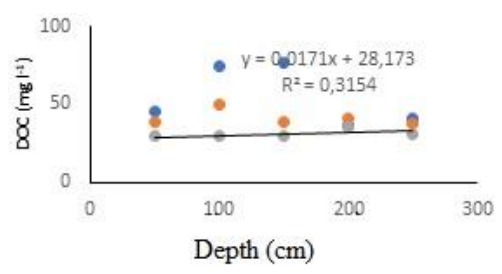

Figure 4 DOC Correlation Regression with Groundwater Depth

are, the more peat will be lost, and automatically makes WT lower or closer to the surface. The number and area of different fire s will also result in changes in the physical, chemical and microbiological properties of peat, which will indirectly affect the dynamics of WT (Hirano et al., 2014).

In addition, previous different land uses also affect the dynamics of WT in these burned lands (Kononen et al., 2015). Harsoyo (2010), various hydrological simulation models have been developed in developed countries to explain the process of changing rain input into output in the form of river flow by considering the physical characteristics of the land. According to Febrianti (2018), regulation of the groundwater level in peatlands is very important as an effort to prevent peatland fire disasters.

\section{DOC and pH of Water}

Dissolved organic carbon in the degradation location (Table 4) was higher at a depth of $100 \mathrm{~cm}$ and $150 \mathrm{~cm}$ with a value of $73.90 \mathrm{mg} \mathrm{l}^{-1}$ and 76.86 $\mathrm{mg}^{-1}$. In measuring the $\mathrm{pH}$ of the water, the location of the degradation at depths of 100 and $150 \mathrm{~cm}$ has the lowest $\mathrm{pH}$ value, namely: 3.6. The data above is in line with Samosir (2009) stated that the characteristics of peat water have high color intensity (brown red color), high acidity (low $\mathrm{pH}$ value), high organic matter content, while the concentration of suspended particles and ions is low. The concentration of organic matter in peat water can be seen from the color, the darker the color, the higher the organic matter content.

The high concentration and amount of DOC at the degradation site was caused because the degradation site had a higher organic matter content than other locations. In addition to the high 
content of organic matter, the $\mathrm{pH}$ factor of groundwater plays a role in the leaching of DOC, the higher the $\mathrm{pH}$, the lower the leaching of DOC. The range of water $\mathrm{pH}$ values obtained is 3.88 4.32, the composition of organic matter can cause a decrease or increase in the $\mathrm{pH}$ of groundwater, this can happen because the decomposition process of organic matter can produce acid.

In this case, it means that the amount of organic matter content is influenced by the presence of $\mathrm{pH}$ in the groundwater. In the tropics, dissolved organic carbon is relatively higher because warm temperatures stimulate the decomposition of organic matter by microorganisms (Folkowski and Raven, 1997). According to Alianto et al. (2007) light is a limiting factor for the presence of organic matter which is important for the primary productivity of waters. According to Rohyati et al. (2003), brightness is strongly influenced by weather conditions, measurement time, turbidity and suspended solids.

\section{Conclusion}

Based on the results of the study, it can be concluded that there are differences in dissolved organic carbon in 3 (three) degraded land conditions contributing an average DOC of 53.1 $\mathrm{mg} \mathrm{l}^{-1}$, while in forest locations the average DOC contributes $40.95 \mathrm{mg} \mathrm{l}^{-1}$, and at the revegetation site contributed an average DOC of $30.73 \mathrm{mg} \mathrm{l}^{-1}$. From this study, the highest DOC content was at the degradation site with an average of $53.1 \mathrm{mgl}^{-1}$, and the lowest was at the revegetation site with an average of $30.73 \mathrm{mg} \mathrm{l}^{-1}$.

\section{Acknowledgment}

This research activity is the result of collaboration between the Australian Government through ACIAR and the Indonesian Government through the University of Palangka Raya. The authors would like to thank Gambut Kita CSIRO/ACIAR Peatland Project FST/2016/144 for funding this activity. Thanks are also conveyed to the Faculty of Agriculture, University of Palangka Raya and UPT. LLG-CIMTROP, the University of Palangka Raya and the ACIAR team of the University of Palangka Raya who helped the author in his field activities.

\section{References}

Alkhatib, M., T.C. Jennerjahn, and J. Samiaji. 2007. Biogeo-chemistry of the Dumai River estuary, Sumatra, Indonesia, a tropical black-water river. Limnol Oceanogr. 52(6):2410-2417.

Baum, A., T. Rixen, and J. Samiaji. 2007. Relevance of peat draining rivers in central Sumatra for the riverine input of dissolved organic carbon into the ocean. Estuari, Coast and Shelf Sci. 73(3):563570.

Billett M.F, Deacon C.M., Palmer S.M., Dawson J.J.C. and Hope, D. 2006. Connecting organic carbon in stream water and soils in a peatland cachment. Geophy Res. 111:113.

Bolan, N.S., S. Baskaran, and S. Thiagarajan. 1999. Methods of measurement of dissolved organic carbon of plant origin in soils, manures, sludges and stream water. In H.F. Linskens and J.F. Jackson (Eds.): Analysis of Plant Waste Materials. Springer Verlag. Berlin.

Febrianti., Kukuh Murtilaksono dan Baba Barus. 2018. Model Estimasi Tinggi Muka Air Tanah Lahan Gambut Menggunakan Indeks Kekeringan. Jurnal penginderaan jauh dan pengolahan data citra digital vol. 15.

Folkowski, P.G. dan A.J. Raven. 1997. Aquatic Photosynthesis. New York : Blacwell Sciense-USA.

Harsoyo, B. 2010. Review modeling hidrologi das di indonesia. Jurnal Sains \& Teknologi Modifikasi Cuaca.

Hirano, T., Kusin, K., Limin, S., and Osaki, M. 2014. Carbon dioxide emissions through oxidative peat decomposition on a burnt tropical peatland. Global change biology, 20(2), 555-565.

Hope, D., Billett, M. F., Milne, R., and Brown, T. A. V.: 1997. Exports of organic carbon in British rivers, Hydrol. Process., 11, 325344.

IPCC (Intergovernmental Panel on Climate Change). 2014. Supplement to the 2006 IPCC Guidelines for National Greenhouse 
Gas Inventories: Wetlands. Hiraishi, T., T. Krug, K. Tanabe, N. Srivastava, J. Baasansuren, M. Fukuda, and T.G. Troxler (Eds.). Published: IPCC, Switzerland.

Ishikawa, T., Trisliana, Yurenfrie, Ardianor, and S. Gumiri. 2006. Dissolved organic carbon concentration of a natural water body relationship to water color in Central Kalimantan, Indonesia. Limnology 7:143146.

Kononen, M., Jauhiainen, J., Laiho, R., Kusin, K., \& Vasander, H. 2015. Physical and chemical properties of tropical peat under stabilised land uses. Mires and Peat, 16(8), 1-13.

Leenheer, J.A. and J.P. Croue. 2003. Characterizing dissolved: aquatic organic matter. Environmental Science \& Technology 1:18-26.

Moore, S., C.D. Evans, S.E. Page, M.G. Garnett, T.G. Jones, C. Freeman, A. Hooijer, A. Wiltshire, S. Limin, and V. Gauci. 2013. Deep instability of deforested tropical peatlands revealed by fluvial organic carbon fluxes. Nature. 493:660-664.

Moore, S., V. Gauci, C.D. Evans, and S.E. Page. 2011. Fluvial organic carbon losses from a Bornean blackwater river. Biogeosciences. 8:901-909.

Moore, T.R., W. Desouza and J.F. Koprivnjak. 1992. Controls on the sorption of dissolved organic carbon in soils. Soil Science, 154: 120-129.

Muhammad Nuriman, Gunawan Djajakirana, Darmawan, Gusti Z. Anshari. 2015. Metode Alternatif Memperkirakan Konsentrasi Karbon Organik Terlarut dalam Air Saluran Drainase dan Tanah
Gambut. Jurnal Tanah dan Iklim Vol. 39 No. 1, Juli 2015: 1-8

Peraturan Menteri Kessehatan Republik Indonesia, 2010, Jakarta, Nomor 492/MENKES/PER/2010, Tentang Persyaratan Kualitas Air Minum.

Richey, Jeffrey J, Melack A, Aufdenkampe V, Ballester, Hess L. 2002. Outgassing from Amazonian rivers and wetlands as a large tropical source of atmospheric $\mathrm{CO}_{2}$. Nature. 416:617-620.

Ritung, S., Wahyunto, K. Nugroho, Sukarman, Hikmatullah, Suparto, dan C. Tafakresnanto. 2011. Peta Lahan Gambut Indonesia Skala 1:250.000. Balai Besar Penelitian dan Pengembangan Sumberdaya Lahan Pertanian. Bogor.

Rohyati, Tati. Hida dan Husnah. 2003. Produktivitas Primer dan Komunitas Plankton di Danau Buatan Kawasan Pemukiman Organ Permata Indah Jakabaring Palembang. Jurnal Ilmu-ilmu Perikanan dan Budidaya Perairan. Balai Riset Perikanan Perairan Umum, 1(1):114.

Samosir, A. 2009. Pengaruh Tawas dan Diatomea (Diatomaceous Earth) Dalam Proses Pengolahan Air Gambut Dengan Metode Elektrokoagulasi, Skripsi, Departemen Kimia, Fakultas Matematika Dan Ilmu Pengetahuan Alam, Universitas Sumatera Utara, Soewandita, H. 2008. Studi Muka Air Tanah Gambut dan Implikasinya Terhadap Degredasi Lahan Pada Beberapa Kubah Gambut di Kabupaten Siak. JAI 4 (2) : 103-108.

Zadow R. 2009. The Real Dirt on Humic Subtances, Maximum Yield, Canada, p. 4044. 